\title{
MARINE FAUNA OF MLJET NATIONAL PARK (ADRIATIC SEA, CROATIA). 7. ECHIURA
}

\section{DUŠAN ZAVodNIK}

Vitomira Širole-Paje 6, HR-52210 Rovinj, Croatia (e-mail: zavodnik.dusan@gmail.com)

\begin{abstract}
Zavodnik, D.: Marine fauna of Mljet National Park (Adriatic Sea, Croatia). Nat. Croat., Vol. 26, No. 1, 33-44, 2017, Zagreb.

It seems that the only Echiuroid species present in the Mljet National Park is Bonellia viridis. This species is known world wide for its peculiar larval development and sexual dimorphism. The forked proboscis females prefer to live in shallow sublittoral crevices in large stones and similar rocky environments. Divers reported B. viridis to be a rather common marine invertebrate.
\end{abstract}

Key words: Echiura, Bonellia viridis, Adriatic Sea, National Park Mljet.

Zavodnik, D.: Morska fauna Nacionalnog parka 'Mljet' (Jadransko more, Hrvatska). Nat. Croat., Vol. 26, No. 1, 33-44, 2017, Zagreb.

Izgleda da je Bonellia viridis jedina vrsta zvjezdana (Echiura) koju nalazimo u Mljetskom Nacionalnom parku. Radi se o životinji poznatoj širom svijeta zbog posebnog razvoja ličinaka i izrazitog spolnog dimorfizma i načina života odraslih jedinki. Velike ženke s račvastim rilom žive ponajviše između kamenja i u pukotinama strmih i okomitih stijena. Prema opažanjima ronilaca na nekim se mjestima u Nacionalnom parku B. viridis čak može smatrati čestom vrstom.

Ključne riječi: Echiura, Bonellia viridis, Jadransko more, Nacionalni park Mljet.

\section{INTRODUCTION}

In the entire Mediterranean Sea, six species of echiurans (Echiura Newby, 1940) were recorded (Murina, 1984; van DER LAND, 2001; Anonymous, 2008; Biseswar, 2009). However, in the Adriatic Sea only two species were identified: Bonellia viridis Rolando, 1821, and Maxmuelleria gigas (M. Müller, 1852) both belonging to the family Bonellidae Baird, 1868.

In the summers of 1995-2002, the student Thais Society for Underwater Research was engaged in studies of benthic communities and biodiversity of marine fauna in the Mljet National Park. The task was done principally on the basis of visual observations by skin and scuba divers. The work resulted in eight bachelor theses, and in numerous professional and scientific papers published elsewhere in Croatia and abroad.

The present contribution is the seventh in the series on the marine fauna of the Mljet National Park. Except for the paper on echinoderms (ZAvodnIK, 2003) all other contributions appeared in the journal Natura Croatica (Kružić, 2002; LogAN, 2003; Dell' Angelo \& ZaVodNIK, 2004; ŠIletić, 2005; ZAVODNIK, 2016).

\section{HISTORICAL ACCOUNT}

In Adriatic scientific literature echiurids appear only at the beginning of the nineteenth century when big females of a littoral species Bonellia viridis attracted the interest of 
scientists (Rolando, 1821). Males of this species were found in the Adriatic Sea and were recorded three decades later (KowAlEvsKY, 1868; VEYDOvskÝ, 1878). The first critical review of the Adriatic reports was provided by CARUs (1885), followed a century ago by Murina (1984), and ZavodniK (1994).

There are many reports of Echiura in Slovenian and Croatian areas, such as the Istrian peninsula (VAtova, 1928; MarcuZZi, 1972; Matjašič et al., 1975; ZAVODNIK \& ZAvodniK, 1986; SKet et al., 2003), the Kvarner archipelago (ZAvodniK, 1994, 1998), Rijeka Bay (ZAvodniK \& Kovačić, 2000), and in Kornati archipelago (Zavodnik D. and Belamarić J., unpublished results).

\section{MATERIALS AND METHODS}

The research project into benthic communities and faunal biodiversity in the area of Mljet National Park was carried out by high school students in the summer period. With regard to the main topics of research the work was based on visual observations and the collection of sediments and biological material by snorkeling, and skin and scuba divers equipped with scientific and fishing equipment. The work along transects was previously shown to be successful (Orepić et al., 1997; Guidetti et al., 2001; Lipej et al., 2004).

Sixty five diving sites were explored (Fig. 1), mainly during the day. Occasionally, night dives were organised as well. Two to ten divers were involved in each excursion. Observations on deep rock and sand habitats were carried out exclusively by scuba divers.

In the area of interest, hydrology and planktology were not considered. Benthic research occasionally was documented by environmental photography.

The details of the majority of sites studied were presented in papers by Orepić et al. (1997), KRUŽIĆ (2002), ZAVODNIK (2003), and ŠIletić (2005).

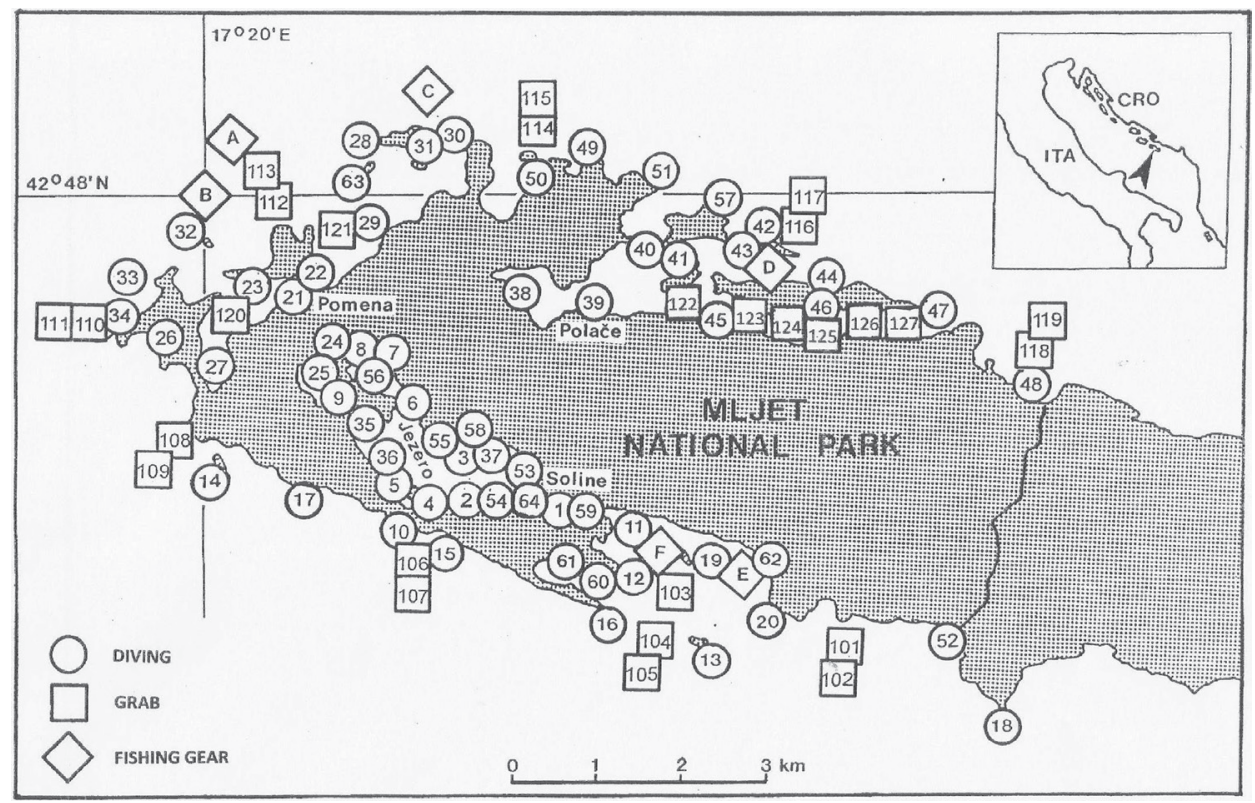

Fig. 1. Research area and surveyed stations. 


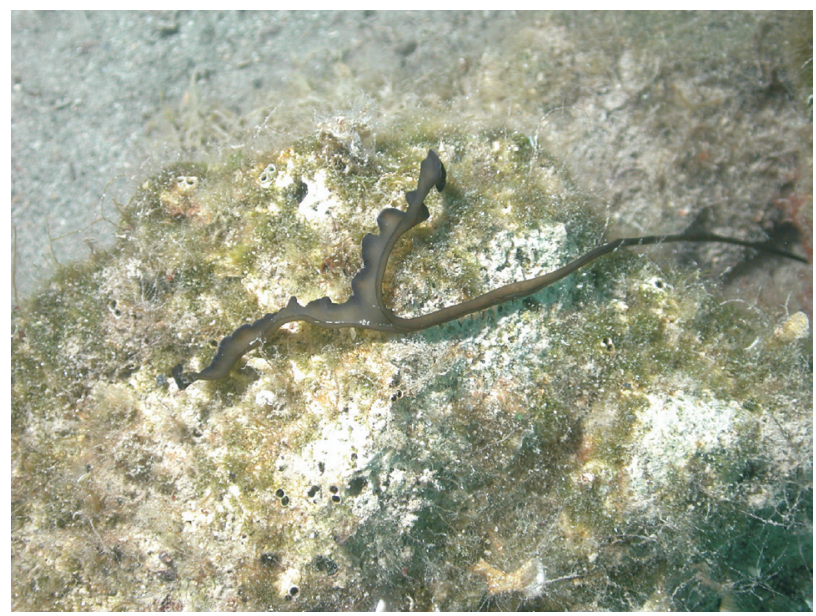

Fig. 2. A female's divided proboscis in a natural environment. (Photo by P. Kružić; taken at Uvala Srednja, Pomena, at $8 \mathrm{~m}$ depth.)

Divers searched in particular for the presence of the forked proboscis of the female B. viridis in subtidal gravel and rocky environments (Fig. 2). Observations were perfomed along a 100 metre long rope marked at one meter intervals, and in 4-10 m path width. At steep reefs and entrances to caves, and vertical or even an overhanding bottom contour depth marks only were considered due to technical reasons.

The presence of big $B$. viridis (females only) was recorded from shallow sea $0.1 \mathrm{~m}$ at low tide, to a maximum $56 \mathrm{~m}$ depth on a vertical rocky wall at Lenga cape - station MLJ-16. At all the studied sites of the research, divers recorded data on rock and boulder morphology and sediments.

To study sediment-dwelling echiurans, numerous grab hauls were done by the research vessel Vila Velebita with an improved Van Veen $0.1 \mathrm{~m}^{2}$ grab type at selected stations (MLJ-101-127). The sediment was sieved through $1 \mathrm{~mm}^{2}$ mesh. Live animals were extracted and preserved in $60 \%$ alcohol or a neutralized $4 \%$ formol solution.

\section{RESULTS}

In the search for echiurans, there were a total of 65 diving sites and 27 grab stations. Divers were usualy engaged in daylight visual observations. No echiurans were found in grab hauls. Similarly, the sediment collected using buckets, and Zahtila hand samplers (Orepić et al., 1997) produced no results. Alas, a postal parcel containing few undeterminable worm pieces preserved in alcohol disappeared during transport to Mrs. Galina V.V. Murina, Odessa (Crimea) who had agreed to examine the material.

While extended, the forked proboscis of an about $10 \mathrm{~cm}$ large Bonellia viridis female can reach about one metre and half in length (GARMS \& BoRM, 1981; present paper). Probosces were noted by divers at our stations MLJ-1, 10, 12, 13, 14, 16, 17, 18, 20, 22, 23, 28, 29, 30, 31, 40, 41, 45, 46, 49, 51, 53, 55 and 59, at 0-45 m depth (Fig. 1, Tab. 1). This species appears to be a typical shade seeking creature, usually inhabiting various rock and similar shelters, and even domestic refuse. Thus Bonellia was detected in some glass bottles drawn up in the course of our bottom cleaning actions at stations MLJ-1 and 
Tab. 1. Basic facts on the sites where Bonellia viridis was found in the Mljet. National Park Exposure abbreviations: Sh - sheltered; Mo - moderately exposed; Ex - exposed to waves.

\begin{tabular}{|c|c|c|c|c|c|c|}
\hline $\begin{array}{l}\text { 总 } \\
\text { 惫声 }\end{array}$ & 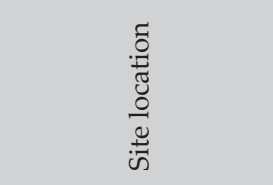 & 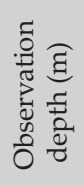 & $\begin{array}{l}\vec{\pi} \\
\stackrel{\pi}{0} \\
\frac{\pi}{\pi} \\
\text { I }\end{array}$ & 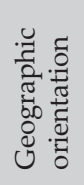 & 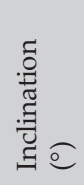 & 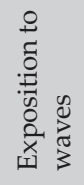 \\
\hline 1 & Soline channel & $0-3$ & Under boulders & E & $0-10$ & Sh \\
\hline 10 & Amfiteatar & $0-2$ & Rock & $\mathrm{S}$ & $0-45$ & Ex \\
\hline 12 & Srednji rat (cape) & $0-9$ & Steep rock & $\mathrm{S}$ & 45 & Ex \\
\hline 13 & Vanji školj & $0-48$ & Steep cliff & SW & $60-90$ & Ex \\
\hline 14 & Štit islet & $0-42$ & Crevices in rocky wall & SW & 90 & Ex \\
\hline 16 & Lenga (cape) & $2-56$ & Crevices in rocky wall & $\mathrm{S}$ & 90 & Ex \\
\hline 17 & Zavrti & $0-32$ & Steep rock, overhang & SW & $0-120$ & Ex \\
\hline 18 & Rat Tojsti (cape) & $0-40$ & Steep rock & SW & $45-90$ & Ex \\
\hline 20 & Hljeb (cape) & $0-20$ & Rock, boulders & SW & $0-90$ & Ex \\
\hline 22 & Sikjerica (cape) & $0-7$ & Gravel, rock & SE & $0-40$ & Mo \\
\hline 23 & Galijica islet & $0-8$ & Gravel, rock, sand, litter & $\mathrm{S}$ & 20 & Sh \\
\hline 28 & Glavat (island) & $0-44$ & Rock, gravel, sand & $\mathrm{W}$ & $10-70$ & Mo \\
\hline 29 & Debeli rat (cape) & $0-47$ & Gravel, rock, sand & NW & $20-90$ & Mo \\
\hline 30 & Rat Glavat (cape) & $0-47$ & Rock, sand & $\mathrm{N}$ & $40-90$ & Ex \\
\hline 31 & Glavat (island) & $3-20$ & Rock, sand & $\mathrm{E}$ & $?-90$ & Mo \\
\hline 40 & Rat Lenga (cape SW) & $0-16$ & Rocky wall & SW & 90 & Ex \\
\hline 41 & Tijesno (strait) & $0-32$ & Rock, sand & S & $30-90$ & Sh \\
\hline 45 & Tratinica (cove) & $0-29$ & Rock, sand & $\mathrm{N}$ & $0-80$ & Sh \\
\hline 46 & Kobrava (island) & $0-40$ & Rock, sand & $\mathrm{S}$ & $45-90$ & Sh \\
\hline 49 & Zazupci (cape) & $5-10$ & Steep holloved wall & $\mathrm{N}$ & $70-90$ & Ex \\
\hline 51 & Rastupa (cape) & $0-45$ & Steep rock, cliff & NE & $45-80$ & Ex \\
\hline 53 & Veli Most (cove) & $0-27$ & Rock, sand, coral reef & $E$ & $30-90$ & Sh \\
\hline 55 & Pristanište & $0-18$ & Gravel, rock, sand & $\mathrm{S}$ & $10-20$ & Sh \\
\hline 59 & Vratosolina & $0-2$ & Gravel, rock & E & $20-45$ & Sh \\
\hline
\end{tabular}

MLJ-55. Rather few probosces of individual female specimens were seen in daylight (Fig. 2), while during night dives their appearance was characterised by divers as "common". Extended probosces measured from $80-147 \mathrm{~cm}$ in length.

\section{BONELLIA VIRIDIS Rolando, 1821}

From a systematic point of view the green spoonworm Bonellia viridis belongs to the phylum Echiura, class Echiuroidea, order Bonellida, family Bonellidae, and the genus Bonellia (Murina, 1984; Biseswar, 2009). Previously, echiurids and sipunculids were systematized in a polyphiletic subclass Gephyrea (QuATrefages, 1865; BAIRD, 1868; Sluiter, 1912; Fischer, 1922), a subclass that is no longer used. It seems that in Adriatic faunistic literature, the term gephyrean was last used by VAтоva (1949). 
Because of its extreme sexual dimorphysm (WILLCZYNSKI, 1960) B. viridis became known world wide, and it is cited and figures in many University text books, in diving manuals as well as academic literature, such as Heller (1864) and BRusina (1907), ZEI \& ZhánĚl (1947), ErCegović (1949), Kaestner (1956), Hyman (1959), RaČAni team (1963), Riedl (1963, 1970), ŠTovičeK-ŠTiRn (1963), Gamulin-Brida (1970, 1974), GARMS \& Borm (1981), CAmpbell (1982), Zavodnik (1994), Turk (1996, 2011), ZavodniK \& Šimunović (1997), Andrić (1999), Ostoić (2000), Hofrichter (2003), Berec et al. (2005), Anonymous (2008), and BAKRAn-Petricioli (2011). The name of this species appeared even in some encyclopaedic sources (Yugoslavian Pomorska enciklopedija: ErCEgović, 1954, 1959; ZEI, 1955; Sovetskaja encikopedija: Anonymous, 1989; Encyclopaedia Britannica: PickFord, 1966; Fauna Europe: GARMs \& Borm, 1981; Živalstvo Slovenije: Sket et al., 2003; Wikipedia, the free encyclopedia: Anonymous, 2016).

With regard to its geographic distribution the species B. viridis was recorded in the eastern Atlantic from Norway and Ireland to the Azores, Canary Islands, Congo, and along the Namaqualano desert coast in Namibia (Murina, 2008). It also was recorded in the Mediterranean and Red Seas, and in the Indian and Pacific Oceans (WikipediA ENCYClopaedia, 2016). Its depth distribution is from 0-50 $\mathrm{m}$ in the Adriatic Sea, and to about $100 \mathrm{~m}$ in the Mediterranean (absent in the Black Sea - Zenkevič, 1963; ANonymous, 1989). Maximum depths noted in other world seas are about 400-2250 m (MurinA, 1984; Biseswar, 2009; Wikipedia encyclopaedia, 2016). Consequently, B. viridis is a subcosmopolitan species, recorded in tropical and temperate seas (MuRINA, 1984), most of all in littoral and circumlittoral zones (PÉRÈs \& PICARD, 1964; present paper). The distribution of Bonellia in the Adriatic Sea recently was reviewed by ZAvoDNIK (1994), and along the Italian coast by ANONYmous (2008).

In the eastern Adriatic, which is characterised by numerous islands, reefs and coves, nocturnal females occur everywhere in sheltered spaces in unpolluted hard bottom habitats, such as free spaces amongst large gravel and loose stones, below boulders, in genuine rock and cliff crevices (ZIMmermanN, 1907; Brusina, 1907; Steuer, 1910; Cori, 1928; ERcegović, 1949; GAMulin-Brida, 1974; Zahtila et al., 2000; present paper), and in shallow water caves (RIEDL, 1966). Much more rarely, it was observed in littoral algal associations and sea grass meadows, or in burrows and shells of dead sessile animals (CORI, 1912, 1928; BAUER, 1928; SCHEMBRI \& JACCARINI, 1978; ZAVODNIK \& ŠIMUNOVIĆ, 1997; BAKRAN-Petricioli (2011); present paper). Surprisingly, B. viridis females' presence was noticed within antique amphorae (PICARD, 1956). However, in the course of similar research conducted in the northern Adriatic, no Bonellia was found (LEGAC, 1974).

Green spoonworm females feed on organic detritus and small benthic animals killed by venomous mucus that is not dangerous to man (MARETIĆ, 1975). In spite of the large adult female proboscis, in the Adriatic area this species was never fished or consumed by the inhabitants (FABER, 1883; BAKIĆ, 1967; ZAVODNIK, 1997), even in times of starvation during war conditions (BAKIĆ \& Popović, 1983).

As far as is known to the present writer, B. viridis is nowhere considered to be an endangered species or protected by law.

\section{DISCUSSION AND CONCLUSIONS}

The echiuran worm Bonellia viridis is the only species of this genus registered in the Adriatic Sea. Another species of the family Bonellidae is Maxmuelleria gigas M. Müller, 1852, which lives in sediments and has been reported from some north Adriatic offsho- 
re and channel stations (Vatova, 1928; Murina, 1984; Zavodnik, 1994; Relini, 2008). According to present knowledge, this second species perhaps is endemic in the area studied (Murina, 1984; SKet et al., 2003; Anonymous, 2008).

The first critical review of the $B$. viridis distribution in the Adriatic Sea was provided by CARus (1885) who highlighted the collections of biological material from the areas of Lošinj and Cres Islands. In his time the only way of finding B. viridis was by the visual observation of seamen, or the occasional catch of specimens. An annotated discussion of knowledge on these matters was presented in a concise review on Adriatic Echiura and Priapulida (ZAVODNIK, 1994). The general distribution patterns of B. viridis in European seas were recently reviewed by VAN DER LAND (2001) and BISESwAR (2009).

In the Adriatic territorial waters of Italy, Echiurids were reviewed recently by Bianchi and Castelli (ANONYMous, 2008), and in Slovenia by MATJAšič \& ŠTiRN (1975), and SKET (2003). Apparently, no recent information is available from the coasts of Bosnia and Herzegovina, and Montenegro. From the sea off Albania some records were provided by SCHEMbri \& JACCARINi (1978), and Dhora (2009).

New records of the presence of females in Croatian waters from two decennia ago (ZAvodnik, 1994) have to be added: Brioni National Park (Veli Brijun Island: Saluga cape, and coves named Dobrika, Javorika, and Verige); Raša Bay (Ubac, Mulac, Tunarica, Prašćarica) (ZAvodnik \& ZAvodniK, 1986); Rijeka Bay: Mošćenićka Draga cove (ZAvodniK \& ZavodniK, 1994); Kvarnerić: Pag Island and Škrda Islet (ZavodniK et al., 2006); Dugi otok Island (Telašćica Bay: Farfarikulac islet); Kornati Archipelago (islets named Balun, Kasela, Lavsa, Levrnaka, Lunga, Mana, Panitula, Rašip, Ravni Žakan), and Kornat Island (Statival cove); Mljet National Park (present paper); Velika Palagruža Island (Veliko žalo, Stara vlaka); Pelješac peninsula (Trpanj); Biševo Island (Modra špilja), and Lastovo Island (Andrić, 1999: Baške stijene; Zavodnik: Skrivena luka) (present paper: Fig. 3; Tab. 2).

The type material of the species was collected from the Sardinian littoral (Rolando, 1828), and in part in the Bay of Trieste, the Lošinj archipelago, and the Vis Island (SCHMARDA, 1852; CARUS, 1885). After the sensational discovery and description of the sexual dimorphism of $B$. viridis, the species' behaviour and habitats were studied. It was confirmed that the females are typical cryptobenthic organisms that live sheltered in

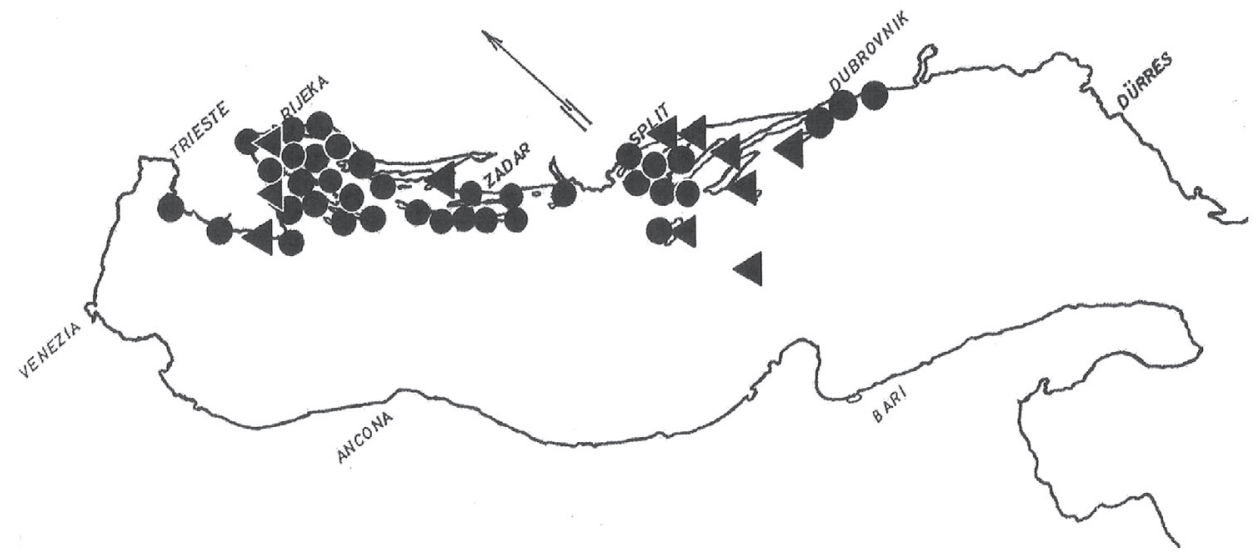

Fig. 3. Bonellia viridis recorded in Croatia. New sites not noted in review by ZavoDNIK (1994) are marked by triangle $(\Delta)$. 
Tab. 2. New finding spots of Bonellia viridis females in Croatia not reviewed previously (ZAvodnIK, 1994). Habitat abbreviations: Alg - Algae, seaweeds; cor - coralligenous bottom; Cym - Cymodocea nodosa; Pos - Posidonia oceanica.

\begin{tabular}{|c|c|c|c|}
\hline Survey areas and sites & Location type & $\begin{array}{l}\text { Depth }(m) \\
\text { surveyed }\end{array}$ & Habitats surveyed \\
\hline VELI BRIJUN & island & $0-8$ & $\operatorname{rock}(\mathrm{Alg})$, sand $(\mathrm{Cym})$ \\
\hline Rt Saluga & cape & $1-8$ & rock $(\mathrm{Alg})$ \\
\hline Javorika & cove & $0-4$ & rock $(\mathrm{Alg})$, sand $(\mathrm{Cym})$ \\
\hline Verige & cove & $2-5$ & rock $(\mathrm{Alg})$ \\
\hline ZALJEV RAŠA & bay & $0-23$ & rock, gravel, sand, mud \\
\hline Rt Ubac & cape & $1-6$ & rock $(\mathrm{Alg})$ \\
\hline Rt Mulac & cape & $10-20$ & rock (Alg), gravel \\
\hline Tunarica & cove & $0-10$ & rock, stones (Alg) \\
\hline Luka & cove & $8-20$ & stones (Alg), sand \\
\hline Prašćarica & cape & $2-23$ & rock $(\mathrm{Alg})$ \\
\hline RIJEČKI ZALJEV & bay & $0-62$ & rock, gravel, sand, mud \\
\hline Mošćenička Draga & cove & $1-5$ & rock, pebbles \\
\hline DUGI OTOK & island & $1-13$ & $\operatorname{rock}(\mathrm{Alg})$, sand $(\mathrm{Cym})$ \\
\hline Farfarikulac & islet & $2-4$ & rock $(\mathrm{Alg})$, sand \\
\hline KORNATSKI OTOCI & archipelago & $0-105$ & rock, cor, sand, mud \\
\hline Balun & islet & $1-3$ & rock \\
\hline Kasela & islet & $0-12$ & $\operatorname{rock}(\mathrm{Alg})$, cor \\
\hline Kornati (Statival) & cove & $0-13$ & rock (Alg), gravel,Pos \\
\hline Lavsa & islet & $0-25$ & rock (Alg), gravel, Pos \\
\hline Levrnaka & islet & $0-12$ & rock $(\mathrm{Alg})$ \\
\hline Lunga & islet & $2-5$ & rock $(\mathrm{Alg})$ \\
\hline Mana & islet & $0-65$ & rock (Alg), (cor) \\
\hline Mala Panitula & islet & $0-12$ & rock $(\mathrm{Alg})$ \\
\hline Rašip & islet & $0-75$ & rock (Alg, cor) \\
\hline Ravni Žakan & islet & $13-35$ & Pos bed \\
\hline ROGOZNICA & harbour & $1-6$ & rock $(\mathrm{Alg})$ \\
\hline BIŠEVO & island & $0-6$ & rock $(\mathrm{Alg})$ \\
\hline Modra špilja & cave & $1-5$ & barren rock \\
\hline VELIKA PALAGRUŽA & island & $0-28$ & rock, stones, sand \\
\hline Veliko žalo & beach & $0-2$ & rock, pebbles \\
\hline Stara Vlaka & cove & $1-4$ & rock, stones \\
\hline PELJEŠAC & peninsula & $0-6$ & rock, sand \\
\hline Trpanj & moorings & $0-3$ & mooring wall \\
\hline $\begin{array}{l}\text { MLJET } \\
\text { National Park }\end{array}$ & $\begin{array}{c}\text { island } \\
\text { beach, islets }\end{array}$ & $\begin{array}{l}0-95 \\
0-56 \\
\end{array}$ & $\begin{array}{l}\text { rock, sand, cor } \\
\text { present paper }\end{array}$ \\
\hline LASTOVO & island & $0-7$ & rock, sand \\
\hline Skrivena luka & cove & $3-7$ & rock, sand \\
\hline
\end{tabular}


tight crevices and spaces below free stones, boulders, and concrete constructions, and in cliffs (RIEDL, 1966). In the sea of Mljet National Park, Bonellia lives in various sheltered places in benthic communities. It frequently benefits from the empty borings of the date mussel (Lithophaga lithophaga) (STEuer, 1910), it occurred in madreporarian coral Cladocora caespitosa bioherms (KRUŽIć, 2001, 2002), in shallow water associations of barnacles Balanus perforatus, and in some subtidal seaweed settlements (present paper). Unfortunately, due to lack of time in the course of our biocoenological research we have not looked for planktonic larvae and dwarf males of this species (SCHMARdA, 1852; VeYdovSKÝ, 1878) living as internal parasites in females.

Consequently, in Croatian shallow waters in the eastern Adriatic rocky bottom $B$. viridis everywhere is a well distributed benthic species, i.e. in the North, Central, and South basins.

\section{ACKNOWLEDGEMENTS}

Firstly, as I start to work on the present manuscript I express my gratitude to Miss Virna Brumnić, Rovinj, and to Mrs Marijana Vuković, Zagreb, for their detective efforts in literature matters. I thank Petar Kružić from the Faculty of Science in Zagreb for providing the photo of B. viridis. Many thanks to Mrs Jill Glen-Perusko, Milton Keynes, UK, for corrections to and improvement of my English.

The study of communities and diversity of marine fauna in the Mljet National Park was initiated and supported by the Thais Society for Underwater Research of Zagreb University. Many thanks to the director and staff of Mljet National Park for official and transport support during our field research, the hospitality of Hotel Odisej and Galija Pension in Pomena village, and especially to Mrs Ana and Mr Pero Sršen in Soline hamlet who frequently provided us with beds and food. I acknowledge herewith the support of the Centre for Marine Research of the Ruđer Bošković Institute in Rovinj, and the staff of its research vessel Vila Velebita for every help in field research.

I am specially obliged to my grandchildren Pamela (Rovinj) and Emanuel (Zagreb) for their invaluable help in the technical adjustment of the manuscript, figures, and tables of the present contribution to Mljet National Park marine fauna. Many thanks to anonymous friends and referees for their comments and suggestions for the improvement of manuscript versions.

Received February 27, 2017

\section{REFERENCES}

Note: In references marked by an asterisk $\left(^{*}\right)$ drawings or photographs of Bonellia viridis are available.

Andrić, M., 1999: Hrvatsko podmorje. Car Herc d.o.o., Zagreb, 274 pp. $\left({ }^{*}\right)$

Anonymous, Redakcionnaja kollegija, 1989: Biologičeskij enciklopedičeskij slovar', Sovetskaja enciklopedija, Moskva, p. 78. (In Russian).

Anonymous, Redazione, 2008: Pogonophora - Echiura, In: Giulio Relini (Ed.), Checklist della flora e della fauna dei mari italiani (Parte I). Biol. Mar. Mediterr., 374-375.

Anonymous, 2016: Bonellia viridis. Wikipedia, the free encyclopedia, 2 pp.

BAIrD, W.B., 1868: Monograph of the species of worms belonging to the subclass Gephyrea. Proc. Zool. Soc. London, 1868, 76-114.

BAKIĆ, J., 1967: „Divlja“ fauna i flora jadranskog područja kao prirodni rezervoar živežnih namirnica. Pomorski zbornik, 5, 791-830. 
Bakić, J., \& Popović, M., 1983: Nekonvencionalni izvori u ishrani na otocima i priobalju u toku NOR-a. In: Pomorska medicina III, Mornarički glasnik, Beograd. Pomorska biblioteka, 33, 49-55.

Bakran-Petricioli, T., 2011: Priručnik za određivanje morskih staništa u Hrvatskoj prema Direktivi o staništima EU. Državni zavod za zaštitu prirode, Zagreb, 184 pp.

BAuER, V., 1928: Über das Tierleben auf den Seegrasswiesen des Mittelmeeres. Z. Jrb. Syst. Ökol. Geogr. Tiere, 56 (1-2), 1-42.

Belamarić, J.: Personal communication.

Belamarić, J. \& D. ŠERMAn, 1989: Ekološka studija podmorja Lokruma. Ekološke monografije, 1, 361-411.

Belamarić, J., D. Zavodnik, E. Zahtila, A. Novosel, N. Orepić, I. Ostoić, T. Radiša, M. Radošević, J.P. ŠKalamera \& J. Vidmar, 1995: Preliminarni rezultati istraživanja makrobentosa uz vanjsku obalu Nacionalnog parka „Mljet“. Ekološke monografije, 6, 545-553.

Berec, L., P.J. SCHEMBri \& D.S. BouKAL, 2005: Sex determination in Bonellia viridis (Echiura: Bonellidae): population dynamics and evolution. Oikos, 108 (3), 473-484.

BISESwAR, R., 2009: The geographic distribution of echiurans in the Atlantic Ocean. Zootaxa, 2222, 17-30.

BRUSINA, S., 1907: Naravoslovne crtice sa sjevero-istočne obale Jadranskog mora, dio četvrti i posljednji. Rad Jugosl. akad. zn. umjet., 171: 42-228.

Campbell, A. C., 1982: The Hamlyn guide to the flora and fauna of the Mediterranean Sea. Hamlyn, London, New York, Sydney, Toronto, 320 pp. $\left(^{*}\right)$

Carus, J.V., 1885: Prodromus faunae Mediterraneae, I.E. Schweizerbart Verl. (E. Koch), Stuttgart, 524 pp.

Cimerman, F., \& M.R. Langer, 1991: Mediterranean Foraminifera. Slov. Akad. znan. umet., Cl. IV \& Znan. raz. Cent. SAZU, Ljubljana. Dela-Opera, 30, 118 pp. + 93 pl.

ConI, C.I., 1912: Characteristik der Fauna der nördlichen Adria. Verh. VIII. Int. Zool.-Kongr. Graz., 1910, 689-711.

Cori, C. I., 1928: Der Naturfreund am Meeresstrande. Emil Haim \& Co., Wien und Leipzig, 174 pp.

CuÉNOT, L., 1922: Sipunculiéns, Échiuriens, Priapuliens. Faune de France, 4 (14), 18-24. ( $\left.{ }^{*}\right)$

Cukrov, M., H. BilandžIIJA, N. Cukrov \& B. Jalžıć, 2011: Anhialini speleološki objekti na području otoka Mljeta. In: Durbešić P. \& Benović A. (Eds), Zbornik radova Simpozija „Dani Branimira Gušića“, Nove spoznaje iz prirodoslovlja otoka Mljeta. Ekološke monografije, 9, 271-278.

Dell'angelo, B. \& D. Zavodnik, 2004: Marine fauna of the Mljet National Park (Adriatic Sea, Croatia). 4. Mollusca: Polyplacophora. Nat. Croat., 13 (4), 319-341.

Dhora, D., 2009: Regjistër i specieve të faunës së Shqipërisë. Camaj-Pipa, Shkodër, 208 pp.

Draganović, E., 1980: Litoralne biocenoze Mljetskih jezera i problemi njihove zaštite (Mimeo). Mr. Sc. Thesis, Sveučilište u Zagrebu, 66 pp.

ERCEGović, A., 1949: Život u moru. Biologijska oceanografija. JAZU, Zagreb, 412 pp.

Ercegović, A., 1954: Bentos (Bental). Pomorska enciklopedija, Leksikografski zavod FNRJ, Zagreb, 1, 441-447.

ERcegović, A., 1959: Parazitizam u moru. Pomorska enciklopedija, Leksikografski zavod FNRJ, Zagreb, 6, 44 .

FABER, G.L., 1883: The fisheries of the Adriatic and the fish thereof. Quaritsch, London, $292 \mathrm{pp}$.

Fischer, W., 1922: Gephyreen des Reichsmuseum zu Stockholm, Ak. Zool., 14 (19), 1-39.

Gamulin-Brida, H., 1970: Nalazi Bonellia viridis u Jadranskom moru (Personal communication). Int. Symp. on the biology of the Sipuncula and Echiura, Kotor 18-25.6.1970.

Gamulin-Brida, H., 1974: Biocoenoses benthiques de la Mer Adriatique, Acta Adr., 15 (9), 1-103.

GARms, H. \& L. Borm, 1981: Razred Zvjezdani (Echiurida). Fauna Europe. Mladinska knjiga, LjubljanaZagreb, 462-463. $\left(^{*}\right)$

Graefre, E., 1905: Übersicht des Fauna des Golfes von Triest - Vermes, Arb. Zool. Inst. Wien, 15, 317-332.

Grube, E., 1861: Ein Ausflug nach Triest und Quarnero. Nikolaische Verl., Berlin, 175 pp.

Grube, E., 1864: Die Insel Lussin und ihre Meeresfauna. F. Hirt, Breslau, 113 pp.

Grubelić, I., 1992: Comparative studies of littoral biocenoses of the Kornati Islands. Acta Adriat., 33, $127-161$.

GrubeLIĆ, I., 1997: Osnovna obilježja bentoske faune otoka Purara, posebno zaštićenog dijela Nacionalnog parka „Kornati“. In: M. Meštrov, P. Durbešić \& M. Kerovec (Eds), Kornati. Hrvatsko ekološko društvo etc., Zagreb, Ekološke monografije, 7, 257-266.

Guidetti, P., S. Busotti \& F. Boero, 2001: Fish visual census in shallow meadows of Mediterranean smallsized seagrasses. Rapp. Comm. int. Mer Médit., 36, 391.

Heller, C., 1864: Horae Dalmatinae. Abh. zool.-bot. Ges.Wien, 14, 17-64. 
Hofrichter, R., 2003: Das Mittelmeer, III. Spektrum Akademischer Verlag, Heildelberg und Berlin, 859 pp.

Hyman, L.H., 1959. The invertebrates. 3. Smaller coelomate groups. Acanthocephala, Aschelminthes, and Entoprocta, and the pseudocoelomate Bilateria. Mc Graw Hill. Comp., New york, 572 pp.

Jaklin, A. \& M. Arko-Pijevac, 1997: Benthic biocoenoses of the St. Marko islet (Rijeka Bay). Period. biol., 99, 219-228.

KaEstNeR, A., 1956: 8. Stamm: Echiurida. In: Lehrbuch der Speziellen Zoologie. I., 2, 342-350. ( $\left.{ }^{*}\right)$

Kowalevsky, V.O, 1868: O planarieobraznom samcy bonelij (in Russian, not seen).

KRužić, P., 2001: Grebenaste tvorbe vrste Cladocora caespitosa (L., 1767) (Anthozoa, Scleractinia) u Jadranskom moru. Mr. Sc. Thesis, Sveučilište u Zagrebu, $107+$ XXII p.p.

KRužić, P., 2002: Marine fauna of the Mljet National Park (Adriatic Sea, Croatia). 1. Anthozoa. Nat. Croat., 11 (3), 265-292.

KRUŽIĆ, P.: Personal communication.

KuščER, I., 1963: Od Svetega Marka do Vele luke. In: I. KuščER (Ed.), Sprehodi pod morjem, Državna založba Slovenije, Ljubljana, 70-94. $\left(^{*}\right)$

Legac, M., 1974: Prilog poznavanju litoralne flore i faune otoka Raba. Vijesti muzeal. konzerv. Hr., 23 (5-6), 75-87.

Lipej, L., M. Orlando Bonaca \& T. Makovec, 2004: Raziskovanje biodiverzitete v slovenskem morju. Nacionalni inštitut za biologijo, Morska biološka postaja, Piran, 136 pp.

Logan, A., 2003: Marine fauna of the Mljet National Park (Adriatic Sea, Croatia). 3. Brachiopoda. Nat. Croat., 12 (4), 233-243.

Lorenz, J. R., 1863: Physicalische Verhältnisse und Vertheilung der Organismen im Quarnerischen Golfe. Verl. K. Akad. Wiss., Wien, 379 pp.

MarcuzzI, G., 1972: Le collezione dell'ex Istituto di Biologia marina di Rovigno conservate presso la Stazione Idrobiologica di Chioggia. Atti Mem. Acad. Patavina Sci. Let. ed Arti, Part II: Cl. Sci. Nat., 84, 169-219.

MARETIĆ, Z., 1975: Životinje otrovnice i otrovne životinje Jadranskog mora. Jugosl. Akad. znan. umjet., Zagreb, 120 pp.

Mathew, J., 1976: The geographic distribution of echiurans in world oceans with special reference to the Indian forms. In: M.E. RIce \& M. Todorović (Eds), Proc. Int. Symp. on the Biology of the Sipuncula and Echiura, Kotor, 18-25 June 1970, Naučno delo Press, Beograd, 2, 127-133.

Matjašič, J., A. Avčin, L. KubiK, J. Štirn, T. Valentinčič \& A. Vukovič, 1971: Morska favna in flora Severnega Jadrana. Katalog 1. Portorož, 33 pp. (Mimeo).

Matjašıč, J., J. Štirn, A. Avčın, L. Kubik, T. Valentinčić, T. Velkovrh \& A. Vukovič, 1975: Flora in favna Severnega Jadrana. I. Slov. Akad. znan. umetn., Razr. IV: Hist. nat., Ljubljana, 3-56.

MurinA, G. V., 1984: Sostav i rasprostranenie ehiur Sredizemnogo morja. Tr. Inst. Okeanol., 119, 82-98. (In Russian).

Murina, G., 2008: Bonellia viridis Rolando, 1821. In: Read, G. \& K. Fauchalt (Eds), 2016: World Polychaeta database. World Register of Marine Species, http://www.marinespecies.org/aphia.php?p= taxdetails\&id=110363, on 2016-05-28.

MüLLER, M., 1852: Observationes anatomicae de vermibus quibusdem maritimis. B, 14-22. (not seen).

Newby, W.W., 1940: The embryology of the echiuroid of the worm Urechis caupo. Mem. Am. Philos. Soc., $16,1-213$.

Novosel, M., T. Bakran-Petricioli, A. Požar-Domac, P. Kružić \& I. Radić, 2002: The benthos of the northern part of the Velebit Channel (Adriatic Sea, Croatia). Nat. Croat., 11 (4), 387-409.

Orepić, N., J. Vidmar, E. Zahtila \& D. Zavodnik, 1997: A marine benthos survey in the lakes of the National park „Mljet“ (Adriatic Sea). Period. biol., 99, 229-245.

Osтоѓ, I., 2000: Zaronite u Hrvatskoj. Blue Buble Editor, Zagreb, 245 pp. $\left(^{*}\right)$

PÉRÈs, J. M. \& J. Picard, 1964: Nouveau manuel de bionomie benthique de la Mer Méditerranée. Recl. Trav. Stn. mar. Endoume, 31 (47), 3-137.

PiCARD, J., 1956: Les peuplements benthiques des amphores du Grand-Conglu. Résultats scientifiques des campagnes de la "Calypso“, 2. Ann. Inst. Océanogr., 32, 155-161.

Pickford, G. E., 1966: Echiurida (Echiuroidea). In: Encyclopaedia Britannica, 7, 898-901.

Popisač, A., 2011: Biocenoza livada posidonije (Posidonia oceanica (L.) Delile) u području NP Mljet. Zbornik radova simpozija „Dani Branimira Gušića“, Nove spoznaje iz prirodoslovlja otoka Mljeta. Ekološke monografije, 9, 181-200.

Quatrefages, A. DE, 1865: Gephyriens. Histoire naturelle des Annéles marins et d'eau douce. 2, 608-632. 
RAČANI team, 1963: Sprehodi pod morjem. I. KuščER (Ed.), Državna založba Slovenije, Ljubljana, 143 pp. $(*)$

RIEDL, R., 1963: Stamm Echiurida (Igelwürmer). In: R. RiedL, Fauna und Flora der Adria. Parey, Hamburg und Berlin, 231-233. $\left(^{*}\right)$

RIEDL, R., 1966: Biologie der Meereshöhlen. Parey, Hamburg und Berlin, 636 pp. $\left({ }^{*}\right)$

RiedL, R., 1970: Stamm Echiurida - Igelwürmer. In: R. RiEdL (Ed.), Fauna und Flora der Adria (2. Aufl.), Parey, Hamburg und Berlin, 260-262. (*)

Rolando, I., 1821: Description d'un animal nouveau qui apparient à la classe des Echinodermes. Memorie Reale accad. sci. Torino, 26, 539-556. (not seen)

SCHEMBRI, P. J. \& V. JACCARINI, 1978: Some aspects of the ecology of the echiuran worm Bonellia viridis and associated infauna. Mar. Biol., 47, 55-61.

Schmarda, L. K., 1852: Zur Naturgeschichte der Adria. I. Bonellia viridis. Denkschr. k. Akad. Wiss., 4 (2), $117-140$.

SEnEš, J.: Personal communication.

SKet, B., 2003: Zvezdaši - Echiurida. In: B. SKet, M. Gogala \& V. Kuštor (Ed.), Živalstvo Slovenije. Tehniška založba Slovenije, Ljubljana, p. 155. $\left(^{*}\right)$

SKET, B., M. Gogala \& V. KuŠToR (Eds), 2003: Živalstvo Slovenije. Tehniška založba Slovenije, Ljubljana, $664 \mathrm{pp}$.

Sluiter, C. P., 1912: Gephyriens (Sipunculides et Echiurids) provenant des campagnes de la Princess Alice, 1898-1910. Result. Camp. sci. Prince Albert I., 36, p. 36. (not seen).

Steuer, A. 1910: Biologisches Skizzenbuch für die Adria. Teubner, Lepzig und Berlin, 82 pp. $\left(^{*}\right)$

Sтоssich, A., 1876: Breve sunto sulle produzioni marine del Golfo di Trieste. Boll. Soc. adr. Sci. nat. Trieste, 2, 349-371.

Sтовsісн, M., 1882: Prospetto della fauna del Mare Adriatico. Boll. Soc. adr. Sci. nat. Trieste, 7 (1): 97-171.

ŠILETIĆ, T., 2005: Marine fauna of Mljet National Park (Adriatic Sea, Croatia). 5. Mollusca: Bivalvia. Nat. Croat., 15 (3), 109-169.

Špan, A., A. Požar-Domac, B. Antolić \& J. Belamarić, 1989: Bentos litoralnog područja otoka Lokruma. Ekološke monografije, 1, 329-360.

ŠtovičEK-ŠTiRn, M., 1991: Moj drugi svet. I. Jadranski svet. In: M. Dolenc (Ed.), Podmorski svet in mi. Prešernova družba, Ljubljana, 143-170.

Turk, T., 1996: Živalski svet Jadranskega morja. Državna založba Slovenije, Ljubljana, 496 pp. (*)

Turk, T., 2011: Pod površinom Mediterana. Školska knjiga, Zagreb, 590 pp. $\left({ }^{*}\right)$

VAN der Land, J., 2001: Echiura. In: M. J. Costello, Ch. Emblow \& R. White (Eds), European register of marine species, Mus. natn. Hist. nat. Paris, Patrimoines naturels, 50: 178.

Vatova, A., 1928: Compendio della flora e fauna del mare Adriatico presso Rovigno. Mem. R. Com. Talass. It., 143: 1-614.

Vatova, A., 1949: La fauna bentonica dell'Alto e Medio Adriatico. Nova Thalassia, 1 (3), 1-119 + Tab. VIIXXXVII.

VejDowsKÝ, Fr., 1878: Ueber die Eibildung und die Männchen von Bonellia viridis Rol. Ztschr. Wiss. Zool., 30, 487-498 (not seen).

Vidmar, J., T. ŽerLIĆ \& N. Orepić, 1996: Istraživanje makrobentosa u podmorju otoka Mljeta (1). Priroda, 86 (832), $22-24$.

WiKipedia, the free encyclopedia, 2016.

WillcZYNSKI, J.Z., 1960: On egg dimorphysm and sex determination in Bonellia viridis R. J. Exp. Zool., $143(1), 61-75$.

Zahtila, E., A. Jaklin \& D. Zavodnik, 2000: Prilog faunistici Makarskog primorja. In: M. Kerovec \& P. DuRbEŠIĆ (Eds), Zbornik kongresa Prirodoslovna istraživanja Biokovskog područja, Makarska 1116.10.1993. Biokovo, 2. Ekološke Monografije, 5, 321-326.

ZAvoDNIK, D., 1991: Nekonvencionalni izvori hrane iz mora na tržištu istočnog Jadrana. In: Zbornik radova znanstvenog skupa 'Tisuću godina prvoga spomena ribarstva u Hrvata', Pomena, Zadar, Sali i Split, 10.-18.10.1995., Hrv. Akad. znan. umj., Zagreb, 637-656.

ZavodniK, D., 1994: Distribution and ecology of Echiura and Priapulida on the Adriatic Sea. Period. biol., 96 (4), 459-462. (*)

ZAvoDNIK, D., 1995-2002: Field diaries (unpublished).

ZAvoDNIK, D., 1998: Prilozi morskoj fauni Riječkog zaljeva. 5. Štrcaljci (Sipuncula) i zvjezdani (Echiura). In: M. Arko-Pijevac, M. Kovačić \& D. Crnković (Eds), Prirodoslovna istraživanja riječkog područja, Prirodoslovna biblioteka 1, Prirodoslovni muzej Rijeka, 617-622. 
Zavodnik, D., 2003: Marine fauna of Mljet National Park (Adriatic Sea, Croatia). 2. Echinodermata. Acta Adriat., 44 (2), 105-160.

Zavodnik, D., 2016: Marine fauna of Mljet National Park (Adriatic Sea, Croatia). 6. Leptocardia. Nat. Croat., 16 (2), 213-221.

ZavodniK, D., A. JAKLin, E. Zahtila \& N. ZavodniK, 2002: Životne zajednice morskog dna na području gradske luke Makarska. In: M. Kerovec \& P. Durbešıć (Eds), Zbornik kongresa Prirodoslovna istraživanja Biokovskog područja, Makarska 11-16.10.1993. Biokovo, 2. Ekološke Monografije, 5, 303-312.

Zavodnik, D. \& M. Kovačıć, 2000: Index of marine fauna in Rijeka Bay (Adriatic Sea, Croatia). Nat. Croat., 9 (4), 297-379.

Zavodnik, D. \& M. Legac, 2012: Prirodna obilježja Puntarske drage na otoku Krku (otok Krk, Sjeverni Jadran). In: M. Arko-Pijevac \& B. Surina (Eds), Prirodoslovna istraživanja Riječkog područja, II., Prirodoslovni muzej Rijeka, Prirodoslovna biblioteka, 10, 253-267.

Zavodnik, D., M. LegaC \& T. GluhaK, 2006: An account of the marine fauna of Pag Island (Adriatic Sea, Croatia). Nat. Croat., 15 (3), 65-107.

Zavodnik, D., A. Pallaoro, A. Jaklin, M. Kovačić \& M. Arko-Pijevac, 2005: A benthos survey of the Senj Archipelago (North Adriatic Sea, Croatia). Acta Adriat., 46 (Suppl. 2), 3-68.

ZavodniK, D. \& A. Šımunović, 1997: Beskralješnjaci morskog dna Jadrana. „Svjetlost“ D.D., Zavod za udžbenike i nastavna sredstva, Sarajevo, $219 \mathrm{pp} .\left(^{*}\right)$

ZAvodNIK, D. \& N. ZAvodNIK, 1994: Biološke značajke mora Brseštine. Katedra Čakavskog Sabora, Opatija. Liburnijske teme, 8, 168-178.

ZAvodNIK, N. \& D. ZAvodNIK, 1986: Biološka valorizacija zaljeva Raša. III. Pomorski zbornik, 24 (1), 535554.

ZEI, M., 1955: Crvi, morski. Pomorska enciklopedija, Leksikografski zavod FNRJ, Zagreb, 2, 296-298.

ZeI, M. \& J. ZháNÈL, 1947: Življenje našega Jadrana. Prirodoznanstvena knjižnica, I. Državna založba Slovenije, Ljubljana, $211 \mathrm{pp}$.

ZENKEviČ, L. A., 1963: Biologija morej SSSR. Izdatelstvo Akad. Nauk SSSR, Moskva, 740 pp. (in Russian)

ZimmermanN, R., 1907: Die Tierwelt der blauen Adria. Ztschr. f. Naturwiss., 78, 1-82.

\title{
SAŽETAK
}

\section{Morska fauna Nacionalnog parka Mljet (Jadransko more, Hrvatska). 7. Strcaljci (Echiura)}

\author{
D. Zavodnik
}

Prema dosadašnjim saznanjima stablo štrcaljaca (Echiura) u Jadranskom je moru zastupljeno sa samo jednom porodicom (Bonellidae) i dvjema vrstama: Bonellia viridis Rolando, 1821, na stjenovitom dnu plitkog priobalnog područja, te Maxmuelleria gigas (M. Müller, 1852) koji se zakapa u dubljim područjima pomičnog uglavnom pjeskovitog dna. Zanimljivo je da tipski materijal obje vrste dijelom potječe i s nalazišta u sjevernom dijelu Jadranskog mora (CARUS, 1885).

Prilikom istraživanja studentske udruge „Thais“ u moru Nacionalnog parka Mljet, ronioci su u dnevnim i noćnim zaronima često naišli na obitavališta zelenog štrcaljca Bonellia viridis, ponajviše u procjepima izmedju stijena i kamenja, $\mathrm{u}$ bušotinama drugih organizama (na primjer prstaca Lithophaga lithophaga) pa čak i u nakupinama brambuljka Balanus perforatus. 